\title{
ARTYKUŁY
}

Klio. Czasopismo poświęcone dziejom Polski i powszechnym

PL ISSN 1643-8191, t. 29 (2)/2014, s. 19-40

(c) (1) $\odot$

http://dx.doi.org/10.12775/KLIO.2014.020

JOANNA KARCZEWSKA

(Zielona Góra)

\section{Rozmieszczenie wsi zagrodowych i drobnoszlacheckich w powiecie gnieźnieńskim na przełomie XV i XVI wieku}

Tilkadziesiąt lat temu Włodzimierz Dworzaczek wskazał na potrzebę Lbadania środowiska drobnoszlacheckiego i szlachty zagrodowej jako grupy „... dotąd nieznanej i występującej na terenie, na którym nie przyj-

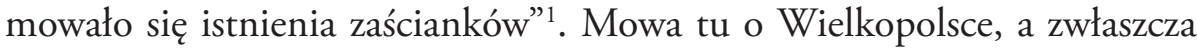
jej wschodniej części, gdzie takowe skupiska drobnoszlacheckie odnajdujemy. Jednak od chwili ogłoszenia tych słów przez W. Dworzaczka stan badań dotyczący szlachty zagrodowej zmienił się w niewielkim stopniu².

1 W. Dworzaczek, Z wielkopolskich zagadnień demograficznych, [w:] Studia nad dziejami społeczeństwa, polityki i kultury dawnej Polski w wiekach XVI-XVIII, opr. Z. Chodyła i Z. Szprys, Warszawa 2010, s. 34.

${ }^{2}$ L. Polaszewski, Szlachta zagrodowa w województwie kaliskim w XVI i XVII wieku, „Rocznik Kaliski” 1975, t. 8, s. 227-247; A. Pośpiech, Majętności na sprzedaż, Wrocław 1989, 84-87; K. Górska-Gołaska, Ciotkowie. Z życia drobnej szlachty wielkopolskiej, [w:] Homines et societas, red. T. Jasiński, T. Jurek, J. M. Piskorski, Poznań 1997, s. 185-203; J. Karczewska, Szlachta czastkowa i zagrodowa $w$ Wielkopolsce $i$ na Kujawach $w$ XV wie- 
Zamierzeniem autorki tego artykułu jest przede wszystkim lokalizacja skupisk szlachty zagrodowej w powiecie gnieźnieńskim na przełomie średniowiecza i czasów nowożytnych, wskazanie na najstarsze wzmianki dotyczące tych wsi oraz przedstawienie uwag toponomastycznych. Podjęto też powiązaną z tym kwestię podziałów tychże wsi i występowania ewentualnych zaników poszczególnych ich części.

Zakres czasowy przedstawionych badań nad środowiskiem drobnoszlacheckim obejmuje przełom XV i XVI wieku. Jest to zatem okres, dla którego liczba źródeł skarbowych jest skromna - są to rejestry poborowe z pierwszej dekady XVI wieku dla powiatu pyzdrskiego, jednak zawierają one niewielki zasób informacji. Natomiast dla powiatu gnieźnieńskiego zachowały się rejestry pochodzące z lat trzydziestych XVI wieku. Podstawę źródłową badań stanowią więc księgi sądów ziemskich i grodzkich, podobnie jak we wspomnianym opracowaniu W. Dworzaczka, tyle, że pochodzące z wcześniejszych lat. Istotnym i pomocnym źródłem, będącym swoistym punktem odniesienia, jest „Liber beneficiorum archidiecezji gnieźnieńskiej”, która ukazuje stan z początku XVI wieku.

W tytule artykułu wskazano dwie kategorie własności szlacheckiej. Jedną z nich reprezentuje szlachta zagrodowa, a więc nie posiadająca kmieci, lecz własnoręcznie uprawiająca swe nieduże gospodarstwa, których powierzchnia mogła obejmować od części łanu do 2-3 łanów. Druga kategoria, czyli własność drobnoszlachecka, dotyczy drobnej szlachty, która posiadała nieduże działy, rozrzucone czasami w kilku wsiach, i dysponowała pracą pojedynczych kmieci. Często we wsiach, w których części posiadała drobna szlachta, żyła też szlachta bezkmieca - właśnie taką sytuację można zaobserwować w średniowiecznym powiecie gnieźnieńskim.

ku, „Społeczeństwo Polski średniowiecznej”, t. 11, red. S. K. Kuczyński, Warszawa 2007, s. 135-153; eadem, Wtasność szlachecka na pograniczu wielkopolsko-kujawskim w pierwszej potowie XV wieku, Kraków 2010, s. 311-331. 


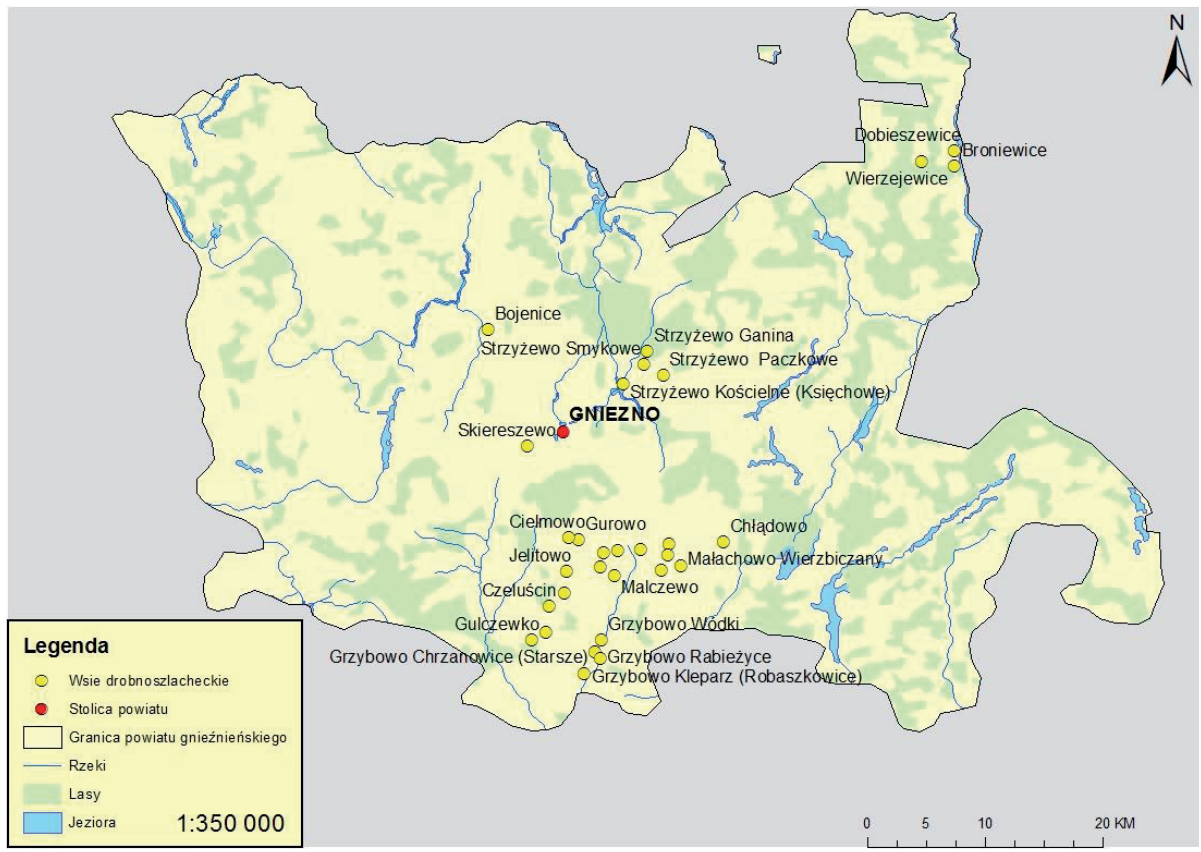

Mapa 1. Powiat gnieźnieński

$\mathrm{Na}$ obszarze powiatu gnieźnieńskiego w województwie kaliskim wsie zagrodowe i drobnoszlacheckie skupiły się w trzech miejscach. Pierwsze z nich, i jednocześnie największe, to obszar na południe od Gniezna - pas między Gnieznem a Witkowem i Czerniejewem. Następny znajdował się w zachodniej części powiatu gnieźnieńskiego (parafie Popowo, Łubowo); kolejny niewielki zespół stanowiło kilka wsi w parafii Trląg.

Charakterystykę wsi zagrodowych w powiecie gnieźnieńskim otwiera Grzybowo, wieś posiadająca kaplicę pełniącą funkcję kościoła parafialnego, ufundowaną przez miejscowych dziedziców. W końcu XV wieku, z powodu niskiego uposażenia, kościół ten został afiliowany do kościoła w Gozdowie ${ }^{3}$. Stosunki własnościowe w Grzybowie niewiele ustępują tym

${ }^{3}$ J. Łaski, Liber beneficiorum archidiecezji gnieźnieńskiej, t. 1, wyd. J. Łukowski i J. Korytkowski, Gniezno 1880, s. 32; Acta capitulorum nec non iudiciorum ecclesiasticorum selecta (dalej cyt.: AC), wyd. Bolesław Ulanowski, t. 2: Acta iudiciorum ecclesiasticorum Gneznensis et Poznanensis (1403-1530), Kraków 1894-1902, nr 374. 
znanym z Mazowsza czy ziemi łukowskiej, a więc z terytoriów częściej kojarzonych jako zamieszkałe przez szlachtę zaściankową, Grzybowo było bowiem okolicą szlachecką. Wieś była podzielona na części, z których każda nosiła dwuczłonową nazwę - pierwszy człon to właściwa nazwa wsi, drugi zaś został urobiony od przydomka - imioniska lub imienia właściciela-dziedzica.

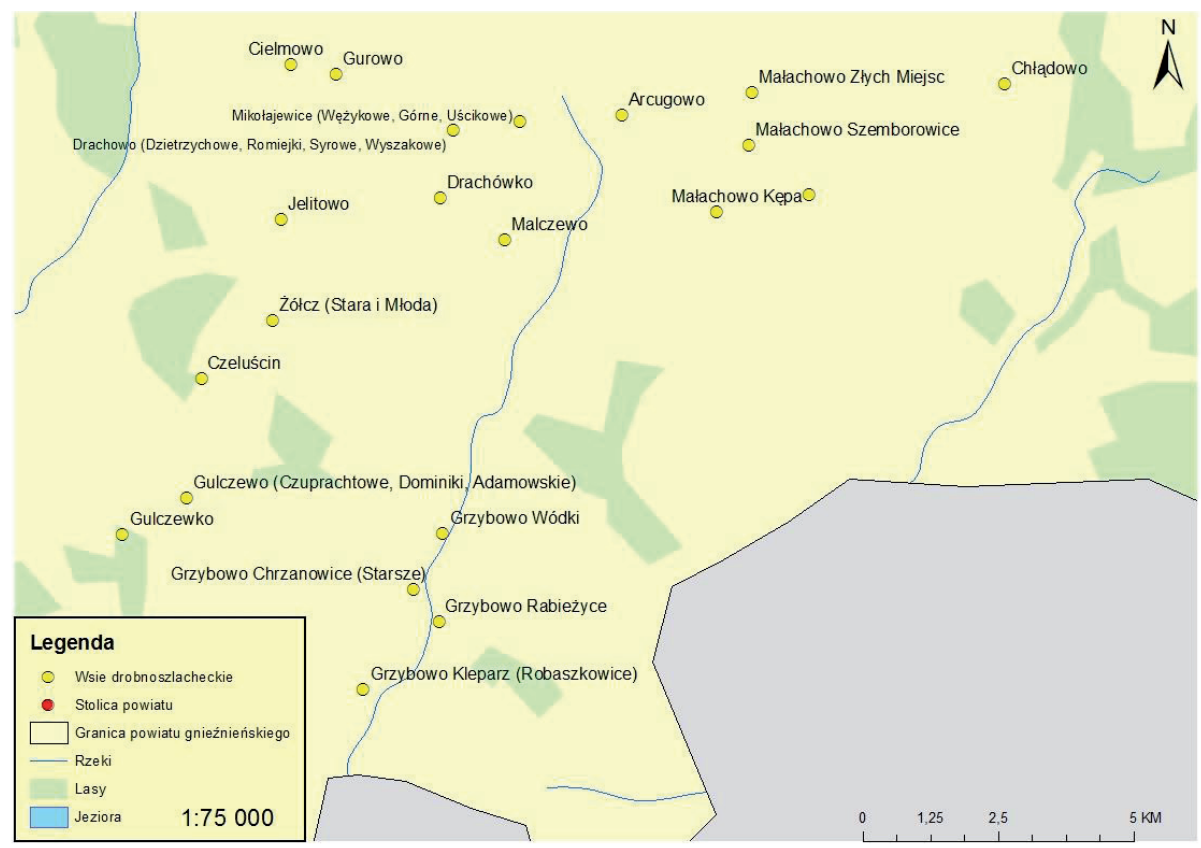

Mapa 2. Ok olice Grzybowa

W XV wieku źródła sądowe wzmiankują 13 różnych działów Grzybowa: Grzybowo Starsze (zwane też Starszą Wsia) ${ }^{4}$, Grzybowo Wódki',

${ }^{4}$ Archiwum Państwowe w Poznaniu (dalej cyt.: APP), Gniezno Gr. 3, k. 44; Gniezno Gr. 4, 30, 30 v, 38, 104.

5 APP, Poznań Gr. 3, k. 89; APP, Gniezno Gr. 4, k. 24v, 108; Die ältesten grosspolnischen Grodbücher, t. 1-2, wyd. J. Lekszycki, Lipsk 1887, t. 2, nr 795. 
Grzybowo Ołowne ${ }^{6}$, Grzybowo Chrzanowice (Crczonowicz) ${ }^{7}$, Grzybowo Rabieżyce (Rabieżyc) ${ }^{8}$, Grzybowo Kleparz ${ }^{9}$, Grzybowo Machowicz ${ }^{10}$, Grzybowo Filipowe ${ }^{11}$, Grzybowo Przecławowo, Grzybowo Witowo, Grzybowo Borzysławowicz ${ }^{12}$, Grzybowo Robaszkowice ${ }^{13}$, Grzybowo Szymonowicz ${ }^{14}$. W zapisce konsystorza gnieźnieńskiego z 1440 roku dotyczącej fundacji kaplicy w Grzybowie wymieniono pięć części Grzybowa: Grzybowo Ołowne, Grzybowo Przecławowo, Grzybowo Borzisławowicz, Grzybowo Witowo i Grzybowo Wódki ${ }^{15}$. Jednakże w zapisce występowały też osoby z charakterystycznymi patronimikami - Szymonowicz, Filipowicz, Machowięta - od których pochodziły nazwy działów Grzybowa. Natomiast Liber beneficiorum Jana Łaskiego wymienia w Grzybowie 7 działów. Były to: Starsza Wieś Grzybowo, Grzybowo Wódki, Grzybowo Rabieżyce, Grzybowo Krzczonowice, czyli Chrzanowice, Grzybowo - Kleparz, Grzybowo Machowicz, Grzybowo Ołowne ${ }^{16}$. Jak pisał wydawca Liber beneficiorum, Grzybowo Machowicz i Grzybowo Ołowne były wymieniane

${ }^{6}$ APP, Gniezno Z. 3, k. 21; APP, Gniezno Gr. 1, k. 134v; APP, Gniezno Gr. 2, k. 202.

7 APP, Gniezno Gr. 4, k. 12, 30v, 36, 38, 107v.

${ }^{8}$ Przydomek Rabiega występuje m.in. w 1440 r. (AC, t. 2, nr 374). Nazwa Grzybowo Rabieżyce zob.: APP, Gniezno Gr. 3, k. 44v, 104; APP, Gniezno Gr. 4, k. 12, 90, 92.

9 Nazwa Grzybowo Kleparz występuje w zapiskach sądowych: Gniezno Gr. 2, k. 181; Gniezno Gr. 4, k. 17v, 21, 35, 40v.

10 APP, Gniezno Gr. 4, k. 31v, 92.

11 Filip z Grzybowa wzmiankowany w: APP, Gniezno Gr. 3, k. 96v; Wielkopolskie roty sadowe XIV-XV wieku, t. 5, wyd. H. Kowalewicz, W. Kuraszkiewicz, Poznań-Wrocław 1981, nr 132 A, 159 A.

${ }^{12}$ Grzybowo Witowo, Przecławowo i Borzysławowicz są wymienione w: AC, t. 2, nr 374.

13 APP, Gniezno Gr. 2, k. 181; S. Kozierowski, Ród Bylinów, „Miesięcznik Heraldyczny" 1913, t. 6, s. 18.

${ }^{14}$ APP, Gniezno Z. 2, k. 29.

${ }^{15}$ AC, t. 2, nr 374. Grzybowo Ołowne - od przydomka Ołowin - Ołowny (Wielkopolskie roty..., t. 5, nr 132 A; S. Kozierowski, Nieznane zapiski heraldyczne, „Rocznik Poznańskiego Towarzystwa Przyjaciół Nauk” 1916, t. 43, nr 41).

${ }^{16}$ Liber beneficiorum..., s. 34. 
także na początku XVII wieku ${ }^{17}$. W opracowaniu Kazimierza Hładyłowicza czytamy jedynie o następujących częściach Grzybowa: Wódki, Kleparz, Chrzanowice, Rabieżyce ${ }^{18}$. Natomiast na współczesnych mapach odnajdujemy Grzybowo, czyli dawne Grzybowo Starsze, oraz wsie o nazwach: Chrzanowice, Kleparz, Wódki, będące w przeszłości częściami Grzybowa.

Rejestr poborowy z 1534 roku wymienia Grzybowo Stare z sześcioma działami, Grzybowo Rabieżyce liczące wtedy 15 działów, Grzybowo Krzczonowice mające pięć działów, Grzybowo Kleparz z pięcioma działami i Grzybowo Wódki, w którym było sześć działów. Poznajemy też imiona dziedziców siedzących na działach w tych przysiółkach ${ }^{19}$. Od tych liczb odbiegają dane pochodzące z rejestru z 1564 roku, który wymienia w Grzybowie Starym trzy działy, w Grzybowie Rabieżycach - pięć działów, w Grzybowie Krzczonowicach - trzy działy, następnie w Grzybowie Machowicz odnajdujemy dwa działy, a w Grzybowie Wódki - pięć działów ${ }^{20}$. Po trzydziestu latach działów w przysiółkach Grzybowa było już znacznie mniej, rejestr z 1564 roku nie wymienił Grzybowa Kleparz, ale pojawiło się Grzybowo Machowicz. Dla pewnego porównania warto wymienić dane liczbowe pochodzące z księgi grodzkiej gnieźnieńskiej obejmującej lata 1474-1482. Z zapisek w niej zawartych wynika, że w Grzybowie Krzczonowicach żyło siedem rodzin szlacheckich, w Grzybowie Starym - trzy rodziny, z Grzybowa Rabieżyc znamy pięć rodzin, z Grzybowa Machowicz - sześć rodzin, w Grzybowie Wódkach mieszkały trzy rodziny, w Grzybowie Kleparz poświadczone były dwie rodziny szlacheckie, a w Grzybowie Ołownym jedna rodzina ${ }^{21}$. To oczywiście też nie są kompletne dane, bo w zapiskach sądowych wymieniono tylko te osoby, które prowadziły przed sadem jakąś sprawę. Dane z księgi grodzkiej są bliższe Liber beneficiorum, przynajmniej w zakresie liczby przysiółków Grzybowa, która w obu tych źródłach jest

17 Ibidem, s. 34, przyp. 1.

${ }^{18} \mathrm{~K}$. Hładyłowicz, Zmiany krajobrazu i rozwój osadnictwa wielkopolsce od XIV do XIX wieku, Lwów 1932, s. 113, 117, 118. Autor ten w dużej mierze opierał się na badaniach S. Kozierowskiego.

19 Archiwum Główne Akt Dawnych w Warszawie (dalej: AGAD), Archiwum Skarbu Koronnego (dalej: ASK), I 12, k. 491v-492.

${ }^{20}$ http://hgis.kul.lublin.pl/mapy

${ }^{21}$ APP, Gniezno Gr. 4, k. 14v. 
taka sama - siedem. Liczba rodzin wskazuje na liczbę możliwych działów; z zapisek sądowych łatwiej wyłuskać informacje o liczbie osób niż o działach majątkowych. Liczba przysiółków w Grzybowie podana w rejestrach odbiega od danych pochodzących ze źródeł sądowych i Liber beneficiorum. Podawanie przez szlachtę do rejestru mniejszej liczby wsi niż faktyczna było często spotykanym zjawiskiem, a miało to na celu obniżenie podatku ${ }^{22}$. W efekcie obraz stanu własności i osadnictwa, jaki rysuje się na podstawie rejestrów, jest niepełny i trochę wypaczony, trzeba go skorygować na podstawie innych źródeł.

W Grzybowie, według słów J. Łaskiego, ...pauci sunt in eis cmethones, solum curiae nobilium ex antiquo ${ }^{23}$. Najważniejszą częścią Grzybowa było Grzybowo Stare, zwane również Starszym lub Większym lub Starszą Wsią; w 1535 roku zostało też określone jako „Grzybowo Stare siue Strzałkowski”24. Siedziała tam m.in. rodzina o przydomku Ćwiekiełka. To właśnie w Grzybowie Starszym w 1440 roku ufundowano i uposażono kaplicę - kościół filialny; grunt, na którym ją zbudowano oraz ogród przekazali Piotr Ćwiekiełka oraz Adam, Andrzej i Jann ${ }^{25}$. W akcie fundacji kaplicy św. Michała w Grzybowie w 1440 roku wymienieni zostali dziedzice z Grzybowa Borzysławowicz - 8 osób, z Grzybowa Przecławowa 2 osoby, z Grzybowa Witowa - 24 osoby $^{26}$, z Grzybowa Wódki (zwane też Wodczicz) - 23 osoby. Ta ostatnia część Grzybowa również miała dawną metrykę. Jej nazwa pochodzi od przezwiska Wódka. W 1399 roku zapiska sądowa wymieniła niejakiego Grzymałę z Grzybowa o przezwisku Wódka ${ }^{27}$. To przezwisko funkcjonowało także w kolejnych pokoleniach dziedziców.

Kolejną wsią zamieszkałą przez zagrodowców było Małachowo, należące do parafii św. Mikołaja w Witkowie. Wieś ta w XV wieku była po-

${ }^{22}$ K. Górska, Przyczynek do krytyki rejestrów poborowych z XVI wieku, „Studia Źródłoznawcze" 1957, t. 1, s. 187.

${ }^{23}$ Liber beneficiorum..., s. 34.

${ }^{24}$ AGAD, ASK, I 12, f. 478; APP, Gniezno Gr. 3, 44; Gr. 4, k. 30, 30v, 38, 104; Liber beneficiorum..., s. 34 .

${ }^{25}$ AC, t. 2, nr 374.

26 AC, t. 2, nr 374.

${ }^{27}$ APP, Poznań Gr. 3, k. 89; Die ältesten..., t. 2, nr 795; Wielkopolskie roty..., t. 5, 159 A. 
dzielona na działy, które również brały nazwę od imienia lub przydomka dziedzica - tak jak w przypadku innych wsi zagrodowych. Były to Małachowo Kępa - zwane w źródłach także Kępicz ${ }^{28}$, następnie Małachowo Szemborowice (Samborowice) ${ }^{29}$, Małachowo Filipowo ${ }^{30}$, Małachowo Wierzbiczany (Wierzbięcice) - zwane też Małachowem Górnym ${ }^{31}$, Małachowo Krzystkowo ${ }^{32}$ i Małachowo Złych Miejsc - znane też pod nazwą Złemięsice ${ }^{33}$, pochodzącą od przydomka Złe Mięso, który pojawił się już w XIV wieku, a był używany również przez kolejne generacje dziedziców. W Liber beneficiorum czytamy natomiast o Malachowo quatuor villae et quinta Malachowo deserta. Jak rozwiązał wydawca, były to: Małachowo Samborówko, Małachowo Złych Miejsc, Małachowo Kępa, Małachowo Wierzbiczany i Małachowo Szemborowice ${ }^{34}$. Wydaje się, że niesłusznie rozdzielił Małachowo Samborówko i Małachowo Szemborowice, których nazwa wywodzi się od imienia Sambor, pojawiającego się wśród miejscowych dziedziców. Dość efemeryczne były działy tej wsi o nazwach odimiennych - Małachowo Krzystkowice i Małachowo Filipowe. Pierwsze z nich było poświadczone w latach 1472 i $1494^{35}$, Małachowo Filipowe zaś w latach sześćdziesiątych XV wieku ${ }^{36}$. Na początku XVI wieku w tych wsiach nullus est cmetho, solum nobilium curiae et aratura, in qua solum habentur duo cmethones $^{37}$. Z lektury XVI-wiecznych rejestrów poborowych jawi się

${ }^{28}$ APP, Gniezno Z. 4, k. 157; APP, Gniezno Gr. 4, k. 68v, 80; APP, Poznań Gr. 8, k. 223.

29 Wśród szlachty z Małachowa imię Sambor pojawiało się niejednokrotnie, znamy m.in.: kasztelana zbąskiego Sambora z Małachowa, który pełnił swój urząd w latach 1411-1419, a w latach 1420-1436 godność łowczego kaliskiego (Urzędnicy wielkopolscy XII-XV wieku. Spisy, opr. M. Bielińska, A. Gąsiorowski, J. Łojko, Wrocław 1985, s. 167), czy inną osobę o tym imieniu znaną m.in. w 1430 r. (Wielkopolskie roty..., t. 5, nr 336 A)

30 APP, Poznań Gr. 6, k. 97.

31 W. Dworzaczek, op. cit., s. 10

32 APP, Poznań Gr. 7, k. 50; APP, Poznań Gr. 8, k. 304.

33 APP, Gniezno Z. 2, k. 78v; APP, Gniezno Gr. 3, k. 48; APP, Poznań Gr. 7, k. 370; Die ältesten..., t. 2, nr 1046.

${ }^{34}$ Liber beneficiorum..., s. 39.

35 APP, Poznań Gr. 7, k. 50; APP, Poznań Gr. 8, k. 304.

36 APP, Poznań Gr. 6, k. 97.

37 Liber beneficiorum..., s. 23. 
już inny obraz: w 1535 roku wymieniono Małachowo Szemborowice z sześcioma działami, Małachowo Złych Miejsc (Złemięsice) miało osiem działów oraz Małachowo Filipowe - cztery działy ${ }^{38}$. Z kolei rejestr poborowy z 1564 roku powtarza dwa przysiółki, tj. Małachowo Szemborowice z czterema działami i Małachowo Złych Miejsc z trzema działami, wymienia za to niewystępujące we wcześniejszym rejestrze Małachowo Wierzbięcice liczące cztery działy i Małachowo Kępe z jednym działem ${ }^{39}$.

Z kolei K. Hładyłowicz w swym opracowaniu wymienił Małachowo Wierzbiczany, Małachowo Szemborowice, Małachowo Złych Miejsc i lokował je w parafii Małachowo ${ }^{40}$. Podał także Małachowo Kępe, ale uczynił to na podstawie źródła późnego, bo pochodzącego z 1580 roku, a ten dział Małachowa znany był już wcześniej. Ponadto K. Hładyłowicz umieścił Małachowo Kępe w parafii Jarząbkowo, a nie w witkowskiej, do której należały inne działy tej wsi ${ }^{41}$. Natomiast na współczesnych mapach odnajdujemy: Małachowo Złych Miejsc, Małachowo Kępa i Małachowo Szemborowice.

Warto nadmienić, że do średniowiecznej parafii witkowskiej należała wieś szlachecka Wygroszewo, która z czasem zanikła. Hładyłowicz wymienił Wygroszewo jako istniejące w okresie 1300-1400, jednak wieś istniała i później, w XVI wieku. Źródła sądowe z drugiej połowy XV wieku wymieniają dużą liczbę dziedziców piszących się „z Wygroszewa”, co wskazywałoby, że również była to wieś drobnoszlachecka ${ }^{42}$. W rejestrze poborowym z 1535 roku odnotowano sześciu dziedziców z Wygroszewa: Mikołaja, Wawrzyńca Wygroszewskiego, Marcina, Mikołaja, Jakuba Wygroszewskiego i Jana Drachowskiego ${ }^{43}$. W 1564 roku w Wygroszewie było pięć działów jednołanowych, należących do dziedziców piszących się Wygroszewskimi. Spośród nich jednak tylko jeden dział jednołanowy

\footnotetext{
38 AGAD, ASK I 12, k. 492 v.

${ }^{39}$ http://hgis.kul.lublin.pl/mapy

${ }^{40}$ K. Hładyłowicz, op. cit., s. 114.

41 Ibidem, s. 121.

${ }^{42}$ J. Karczewska, Wtasność szlachecka..., s. 316.

43 AGAD, ASK, I 12, k. 493 v.
} 
był łanem uprawnym w „oraninie własnej”, pozostałe natomiast obejmowały łąki ${ }^{44}$.

Do parafii w Jarząbkowie należały, jak czytamy w Liber beneficiorum, dwa Jelitowa, jednak źródło nie wymienia nazw członów wsi. Poznajemy je z zapisek sądowych z 1494 roku - były to Jelitowo Maćkowe i Jelitowo „Szwijakowo" ${ }^{5}$. W pobliżu Jelitowa położona była też osada o nazwie Wiewiórczyno. W 1494 roku działy w Jelitowie „Szwijakowo” i w Wiewiórczynie sprzedała Małgorzata Świniarska, mieszczka z Kalisza. Ich nabywcą był Maciej z Małych Gałązek ${ }^{46}$. W tym samym roku mieszczka z Wrześni, Helena Jelitkowska, sprzedała swą ojczystą część w Jelitowie Maćkowym za 10 grzywien Mikołajowi Koniecznemu z tegoż Jelitowa ${ }^{47}$. Działy wsi znajdujące się w rękach mieszczek szlacheckiego pochodzenia też świadczą o drobnoszlacheckim statusie tych osad, kobiety wywodzące się z takiego środowiska były bowiem chętnie wydawane za mąż za mieszczan. W 1535 roku w Jelitowie było aż sześć działów, a w 1564 roku już cztery $^{48}$. Wzmiankowanego przez zapiski sądowe Wiewiórczyna nie wymieniają Liber beneficiorum ani rejestry poborowe, nie znał tej wsi także K. Hładyłowicz. Obecnie to wieś zaginiona, możliwe, że została wchłonięta przez sąsiednią.

Do parafii jarząbkowskiej należały też dwie wsie o nazwie Żółcz (Żołcz), tzn. Żółcz i Żółcz Mała ${ }^{49}$. Wioski te nazywano również Źłółcz Stara i Żółcz Młoda ${ }^{50}$. Według K. Hładyłowicza, Żółcz Młoda po 1523 roku zanikła $^{51}$, jednak jest to błędne mniemanie, ponieważ była ona wymieniana także później, choćby w rejestrach poborowych z lat 1564 i 1581 . Wynika z nich, że w 1564 roku w Żółczy Młodej było pięć działów jednołanowych a w Żółczy Starej aż siedem działów, z których jeden liczył pół łanu, pozo-

\footnotetext{
${ }^{44}$ http://hgis.kul.lublin.pl/mapy

45 APP, Poznań Gr. 7, k. 93, 102.

46 APP, Poznań Gr. 7, k. 102.

${ }^{47}$ Ibidem, k. 93.

${ }^{48}$ AGAD, ASK I 12, k. 492; http://hgis.kul.lublin.pl/mapy

49 Liber beneficiorum..., s. 26.

50 W. Dworzaczek, op. cit., s. 13.

${ }^{51}$ K. Hładyłowicz, op. cit., s. 121.
} 
stałe jeden łan ${ }^{52}$. W 1581 roku w Żółczy Starej siedziało natomiast pięciu dziedziców posiadających po pół łanu ziemi i jeden będący właścicielem działu o powierzchni 3/4 łanu. Z kolei w Żółczy Małej trzech dziedziców posiadało działy o powierzchni 1 łanu, jeden zaś siedział na dziale półłanowym $^{53}$. W tej samej parafii znajdowały się Michałkowice, określone w dziele Łaskiego jako „deserta” ${ }^{4}$. Hładyłowicz zaś pisał, że Michałkowice to „dziś pole tej nazwy na Żółczu" "55, był to więc w średniowieczu jakiś dział Żółczy. Autor ten wymienił także zanikłą osadę Wypęczyno koło Jarząbkowa (znaną w 1466 roku $)^{56}$. W dziele Łaskiego też wspomniano „Vypyczyno”, które było wtedy opustoszałe. Wydawca wyraził przypuszczenie, że może jest to obecna wieś Babiak ${ }^{57}$. Według Liber beneficiorum we wsiach Żółcz, Jelitowo i Michałowice nullus est kmetho ${ }^{58}$.

Do parafii w Jarząbkowie należało także Malczewo, w którym na początku XVI wieku były trzy dwory szlacheckie ${ }^{59}$, oraz Czeluścin - wieś również o statusie drobnoszlacheckim, w której działy posiadała drobna szlachta z sąsiednich osad.

W nieodległej parafii Marzenin położone było Gulczewo duplex ${ }^{60}$. Chodzi tu o Gulczewo zwane Czuprachtowe i Gulczewko ${ }^{61}$. W poblizu Gulczewa leżaty Dominiki (Domynyky), był to dział Gulczewa - wśród miejscowej szlachty pojawiało się imię (przydomek) Dominik ${ }^{62}$. W 1468 roku wzmiankowana była część Gulczewa nazywana Adamowska ${ }^{63}$. Rejestr po-

52 http://hgis.kul.lublin.pl/mapy

53 A. Pawiński, Polska XVI wieku pod wzgledem geograficzno-statystycznym. Wielkopolska, t. I, Warszawa 1883, s. 147.

54 Liber beneficiorum..., s. 26.

55 K. Hładyłowicz, op. cit., s. 120.

56 Ibidem.

57 Liber beneficiorum..., s. 25-26.

58 Ibidem, s. 25.

59 Liber beneficiorum.., s. 26.

${ }^{60}$ Ibidem, s. 28.

${ }^{61}$ AC, t. 2, nr 1657; K. Hładyłowicz, op. cit., s. 113, 115.

${ }^{62}$ Wymienia je W. Dworzaczek, op. cit., s. 15. Autor ten przytacza późniejsze nazwy działów w Gulczewie - Gulczewo Bobolino i Gulczewo Adamowskie. To ostatnie wzięło nazwę od XV-wiecznej części wsi, może będącej nazwą włóki - Adamowska.

${ }^{63}$ APP, Gniezno Gr. 3, k. 54 v. 
borowy z 1564 roku wzmiankuje jeszcze Gulczewo Bobolino z trzema działami oraz Gulczewo Czuprachtowe, bez wskazania własności ${ }^{64}$. W miejscowościach tych mieszkali liczni nobiles et pauci cmethones ${ }^{65}$. Pojedynczy kmiecie faktycznie w Gulczewie gospodarowali, np. w 1476 roku zapiska sądowa wymieniła kmiecia Wojciecha Chudka ${ }^{66}$. Miejscowi dziedzice byli też właścicielami części w sąsiednich wsiach drobnoszlacheckich i zagrodowych - Stanisław Gulczewski posiadał część w Grzybowie, a Paweł Gulczewski, alias Wythacowski, miał część w Cielmowie ${ }^{67}$.

Jeszcze jedną typowo zagrodową wsią były Bojenice należące do parafii św. Piotra na przedmieściach Gniezna; prawo patronatu tego kościoła należało do miejscowych dziedziców. W 1476 roku Małgorzata, żona Marcina z Sobiesierni i jej brat, Paweł Gulczewski, sprzedali swą ojczystą i macierzystą część w Bojenicach łącznie z prawem patronatu kościoła św. Piotra Wojciechowi z Bojenic za kwotę 230 grzywien. Na początku XVI wieku we wsi nie było żadnego kmiecia, a jedynie sześć dworów szlacheckich, właścicieli niektórych z nich wymienia Liber beneficiorum: Michał Kaczkowski, Katarzyna, wdowa po Stanisławie Konieczko, Mikołaj i Piotr Konieczko oraz Wawrzyniec Giza. Według rejestru poborowego z 1535 roku w Bojenicach było siedem działów liczących od 1/2 do 1 łanu ziemi $^{68}$. Po trzydziestu latach, w 1564 roku, znajdowały się tam już tylko cztery niewielkie działy, liczące 1-2 łany, ale były to już łany kmiece, a nie w „oraninie własnej” ${ }^{\circ}$. Hładyłowicz nie wymienił wsi Bojenice w swym opracowaniu. Obecnie osada ta nie jest znana.

Wsią zamieszkaną przez szlachtę zagrodową było też Cielmowo, należące do gnieźnieńskiej parafii św. Wawrzyńca. W czasach J. Łaskiego znajdowało się tam pięć dworów szlacheckich i nie było żadnego kmie$\mathrm{cia}^{70}$. W połowie XVI wieku, według rejestru z 1564 roku, stan własności w Cielmowie niewiele się zmienił. Poznajemy dwunastu dziedziców

\footnotetext{
${ }^{64}$ http://hgis.kul.lublin.pl/mapy

${ }^{65}$ Liber beneficiorum..., s. 28.

${ }^{66}$ APP, Gniezno Gr. 4, k. 18.

${ }^{67}$ APP, Gniezno Gr. 4, k. 30 v; APP, Gniezno Gr. 7, k. 268.

68 AGAD, ASK I 12, k. 490 v.

${ }^{69}$ http://hgis.kul.lublin.pl/mapy

${ }^{70}$ Liber beneficiorum..., s. 11-12.
} 
gospodarujących na pięciu działach o powierzchni jednego łanu „oraniny własnej”. Ich właściciele to ośmiu Cielmowskich, trzech Gurowskich i Wawrzyniec Gulczewski; łącznie mieli oni w Cielmowie pięciu zagrodników $^{71}$. Zagrodnik płacił 2 grosze podatku, natomiast szlachta - po 12 groszy z uprawianego przez siebie łanu ${ }^{72}$.

Kolejną wsią zagrodową w pobliżu Gniezna były Mikołajewice należące do parafii św. Jakuba w Niechanowie. W czasach J. Łaskiego nie było w tej wsi żadnego kmiecia, a tylko dwory szlacheckie. Czytamy też w Liber beneficiorum, że były trzy Mikołajewice, jednak źródło nie wymienia nazw działów tej wsi ${ }^{73}$. Hładyłowicz natomiast pisał o Mikołajewicach Wężykowych ${ }^{74}$. Przydomek Wężyk pojawiał się wśród dziedziców tej wsi w XV wieku - w 1481 roku wystąpili Marcin Wężyk i Jan Wężyk ${ }^{75}$; z kolei W. Dworzaczek znał Mikołajewice Górne, Nadolne i Uścikowe ${ }^{76}$. W 1564 roku w Mikołajewicach Wężykowych były dwa działy o powierzchni jednego łanu, lecz były to łąki ${ }^{77}$. Rejestr poborowy z 1581 roku wymienił jedynie pojedyncze jednołanowe działy w Mikołajewicach Górnych i Wężykowych ${ }^{78}$.

Do parafii św. Wawrzyńca w Gnieźnie należała wieś drobnoszlachecka Drachowo, jednak bezpośrednio podlegała ona kościołowi filialnemu w Gurowie, podobnie jak Cielmowo ${ }^{79}$. W XV wieku Drachowo było podzielone na następujące części: Drachowo Dzietrzychowe (zwane też Wietrzychowym) ${ }^{80}$, Drachowo Romiejki (Rumiejki) ${ }^{81}$, Drachowo

${ }^{71}$ AGAD, ASK, I 12, k. 561v.

${ }^{72}$ Ibidem.

${ }^{73}$ Liber beneficiorum..., s. 21-22

${ }^{74}$ K. Hładyłowicz, op. cit, s. 114.

${ }^{75}$ APP, Gniezno Gr. 4, k. 82, 104.

76 W. Dworzaczek, op. cit., s. 14.

77 http://hgis.kul.lublin.pl/mapy

${ }^{78}$ A. Pawiński, op. cit., s. 151.

${ }^{79}$ Liber beneficiorum..., s. 11-12, 41.

${ }^{80}$ APP, Gniezno Gr. 4, k. 114v; APP, Poznań Gr. 7, k. 54.

${ }^{81}$ APP, Gniezno Gr. 2, k. 61, 188; APP, Poznań Gr. 8, k. 164; Wielkopolskie roty..., t. 5, nr 223 A. 
Syrowe $^{82}$ i Drachowo Wyszakowe ${ }^{83}$ - ich nazwy pochodziły naturalnie od imion i przydomków właścicieli. Sporadycznie księgi sądowe wymieniały po prostu Drachowo maior ${ }^{84}$, a jeśli tak, to byto i Drachówko - osada Minor Drachowo wymieniona była w 1425 roku w dokumencie dotyczącym konfliktu o prawo patronatu kościoła św. Wawrzyńca w Gnieźnie, którego jedną ze stron była szlachta z Drachowa, Gurowa, Cielmowa, Małachowa, Goczałkowa i Arcugowa ${ }^{85}$. Liber beneficiorum Łaskiego informuje jedynie o trzech Drachowach, a rejestr poborowy z 1564 roku wzmiankuje też, nieznane wcześniej, Drachowo Kopciowe z pięcioma działami ${ }^{86}$. Ten sam rejestr wymienia jeszcze Drachowo Romiejowe $\mathrm{z}$ pięcioma działami ${ }^{87}$. Natomiast K. Hładyłowicz wymienia Drachowo oraz Drachówko, które umieszcza w parafii gnieźnieńskiej, ale dopiero pod datą 1580 roku $^{88}$. O skali rozdrobnienia Drachowa może świadczyć liczba osób piszących się z tej wsi, a występujących we wspomnianym wyżej dokumencie dotyczącym sporu o patronat kościoła - z Drachowa pojawiło się 7 osób i 22 osoby z Drachówka ${ }^{89}$.

Kolejne wsie o charakterze drobnoszlacheckim w obrębie parafii św. Wawrzyńca w Gnieźnie to Gurowo i Gurówko. W 1412 roku Gurowo miało własną parafię ${ }^{90}$, a kościół został uposażony przez miejscowego dziedzica Piotra zwanego Pierdziwilk ${ }^{91}$. „Liber beneficiorum” natomiast określa miejscowy kościół jako filialny dla parafii św. Wawrzyńca w Gnieźnie ${ }^{92}$. Ten miejski kościół pełnił jak widać rolę parafialnego dla pobliskich osad zagro-

82 Ta część Drachowa znana dopiero u schyłku XV w. (1497 r.): APP, Poznań Gr. 7, k. 268.

83 APP, Gniezno Gr. 4, k. 37; APP, Poznań Gr. 2, k. 123v; APP, Poznań Gr. 9, k. 50.

${ }^{84}$ APP, Gniezno Gr. 4, k. 104.

${ }^{85}$ Kodeks dyplomatyczny Wielkopolski (dalej cyt.: KDW), t. 7, wyd. A. Gąsiorowski, R. Walczak, Poznań-Warszawa 1985; ibidem, t. 8-10, wyd. A. Gąsiorowski, T. Jasiński, Warszawa-Poznań 1989-Poznań 1993; t. 8, nr 1066.

${ }^{86}$ Liber beneficiorum..., s. 41; http://hgis.kul.lublin.pl/mapy

87 http://hgis.kul.lublin.pl/mapy

${ }^{88}$ K. Hładyłowicz, op. cit., s. 112, 121.

${ }^{89}$ KDW, t. 8, nr 1066.

${ }^{90}$ K. Hładyłowicz, op. cit., s. 118 (na podstawie ksiąg sądowych).

91 W. Dworzaczek, op. cit., s. 12.

92 Liber beneficiorum..., s. 41. 
dowych i drobnoszlacheckich, oprócz wymienionych wsi obejmował posługą duchową także podgnieźnieńskie Skwiroszewo (dzisiejsze Skiereszewo), również rozdrobnione ${ }^{93}$. W przypadku Skwiroszewa własność zagrodowa jest poświadczona $\mathrm{w} \mathrm{XV}$ wieku. Liber beneficiorum informuje już tylko o kmieciach płacących dziesięciny, nie wspominając w ogóle o szlachcie, a w 1564 roku we wsi było pięć łanów kmiecych i żadnego szlachcica zagrodowego ${ }^{94}$.

Do wsi dość mocno podzielonych należało też Strzyżewo położone na północny wschód od Gniezna. Istniało Strzyżewo Smykowe (Smyczkowe), Strzyżewo Paczkowe (Paszkowe), Strzyżewo Ganina (Gonina) i Strzyżewo Kościelne. Takie nazwy części wsi odnajdujemy na kartach ksiąg sądowych $^{95}$. Natomiast w Liber beneficiorum zostało jeszcze wymienione Strzyżewo Księchowe, zabrakło natomiast Strzyżewa Smyczkowego ${ }^{96}$, które zresztą istnieje do dziś. Strzyżewo Kościelne stanowiło własność klarysek gnieźnieńskich, pozostałe Strzyżewa były zaś własnością szlachecką, dziedziczyli tam przedstawiciele rodu Porajów. Nazwy części wsi pochodzą od przydomków właścicieli, które powtarzały się w każdym niemal pokoleniu (Smyczkowicz, Paskowicz).

Wszystkie te wsie należały w XV wieku do parafii Strzyżewo Kościelne. Natomiast według Liber beneficiorum, Strzyzewo duplex tj. Strzyżewo Smykowe i Paczkowe należały do parafii w Dębnicy, wsi także będącej własnością Porajów ${ }^{97}$.

W 1428 roku doszło do limitacji między Strzyżewem Smyczkowym, którego ówczesnymi dziedzicami byli bracia Maciej Smyczkowic, Dobiesław i Adam, a Strzyżewem Kościelnym ${ }^{98}$. W latach 1439-1440 trwał konflikt o prawo prezenty kościoła w Strzyżewie Kościelnym między dziedzicami ze Strzyżewa, Janem Paszkowicem, Janem Smyczkowicem ze Strzyżewa

93 Ibidem, s. 12.

${ }^{94}$ Ibidem, s. 13; http://hgis.kul.lublin.pl/mapy

95 APP, Gniezno Z. 3, k. 118v; APP, Gniezno Gr. 2, k. 178; KDW, t. 9, nr 1483, 1488; S. Kozierowski, Ród Porajów-Różyców, „Rocznik Polskiego Towarzystwa Heraldycznego” 1928-1929, t. 9, s. 116.

${ }^{96}$ Liber beneficiorum..., s. 103.

97 Ibidem, s. 41.

${ }^{98}$ APP, Gniezno Z. 3, k. 118v. 
i Bartoszem z pobliskich Gołąbków, a konwentem klarysek z Gniezna99. Prebendę objął prezentowany przez klaryski Jarosław z Kąkolewa, kanonik gnieźnieński i poznański.

W 1564 roku dwułanowy dział we własnej uprawie i 4 zagrodników w Strzyżewie Smykowym należały do Wojciecha Strzeżewskiego, w Strzyżewie Paszkowym zaś jednołanowy dział obejmujący łąki był w posiadaniu Macieja Miedźwiedzkiego ${ }^{100}$.

W pobliżu Strzyżewa znajdowały się wsie, w których działy posiadali dziedzice Strzyżewa z rodu Porajów. Należało do nich Jastrzębowo w parafii Strzyżewo Kościelne, z którego w 1464 roku bracia niedzielni piszący się ze Strzyżewa Paczkowego zobowiązali się płacić czynsz wikariuszom katedry ${ }^{101}$. W 1469 roku z Jastrzębowa pisał się Mikołaj Strzyżewski ${ }^{102}$. W 1564 roku w Jastrzębowie był półłanowy dział „oraniny własnej”"103.

W parafii Strzyżewo Kościelne leżała wieś Jezierzany, z której w 1410 roku pisali się dziedzice pobliskich Gołąbków, Piotr Rzepka i Mikołaj ${ }^{104}$; w 1420 roku Jezierzany były już własnością prepozyta św. Jana w Gnieźnie - Mikołaja. Doszło wtedy do rozgraniczenia Jezierzan i osady młyńskiej Piściec, która należała do Bartosza z Gołąbków ${ }^{105}$. Granica przebiegała drogą zwaną Zielonki, wiodącą przez bór Jezierzany do lasu w Piśćcu. Zarówno Jezierzany, jak i Piściec oraz Gołąbki, z których pisał się Bartosz, należały do parafii w Strzyżewie Kościelnym. Jezierzany i Piściec znane były jeszcze w czasach Łaskiego ${ }^{106}$, natomiast dziś to wsie zaginione, zapewne wchłonięte przez sąsiednie osady.

W parafii strzyżewskiej znajdowało się również Jakubowo, które znane było jeszcze w XVI wieku a obecnie takiej wsi nie odnajdujemy na mapie. W 1382 roku dziedzice z rodu Porajów sprzedali Jakubowo klasztorowi

99 KDW, t. 10, nr 1483, 1488.

${ }^{100}$ http://hgis.kul.lublin.pl/mapy

101 Archiwum Archidiecezjalne w Gnieźnie, dypl. Gniezno 483.

102 APP, Gniezno Gr. 2, k. 178.

103 http://hgis.kul.lublin.pl/mapy

${ }^{104} \mathrm{KDW}, \mathrm{t} .7$, nr 671.

105 Ibidem, t. 8, nr 897.

${ }^{106}$ Liber beneficiorum..., s. 103. Piściec był położony ok. $10 \mathrm{~km}$ na pn.zach. od Trzemeszna (KDW, t. 8, nr 897, przyp. 19). 
w Trzemesznie, w 1409 roku zaś inny Poraj - Zawisza z Chociczy - bezskutecznie pozywał o tę wieś kanoników trzemeszeńskich ${ }^{107}$.

Nieduży kompleks wsi drobnoszlacheckich odnajdujemy także na pograniczu powiatów gnieźnieńskiego i inowrocławskiego. Były to położone w parafii Trląg Wierzejewice (Wierzeje), Dobieszewice (Dobieszewo) i Broniewice (zwane sporadycznie Broniewem). Pojedyncze działy w tych wsiach należały do różnoherbowych dziedziców Trląga. W XV wieku we wspomnianych wsiach dziedziczyła pewna rodzina, którą, na podstawie posiadanej przez nią własności w Wilamowie, identyfikuję jako przedstawicieli rodu Szaszorów ${ }^{108}$. W 1449 roku pięciu braci dziedziczących w wymienionych wyżej wsiach dokonało między sobą zamiany działów w Dobieszewicach, Broniewicach i Wierzejewicach a także pewnej części Jadownik ${ }^{109}$. Według danych zawartych w rejestrze poborowym z 1580 roku w Broniewicach był trzy drobne działy, należące do Jana Obermuta Kołudzkiego (2 łany kmiece), Bartłomieja Wierzejskiego (1 łan kmiecy) i dział Krzekotowskiego, obejmujący pół łanu kmiecego ${ }^{110}$. Z kolei według danych z rejestru z 1588 roku w Broniewicach, oprócz tych trzech działów, które wówczas miały już innych właścicieli, gospodarowali Maciej i Adam Wierzejscy, uprawiający tam ziemię „oraniną własną”" ${ }^{111}$. Natomiast w Dobieszewicach w 1580 roku był wykazany pewien dział znajdujący się w ręku Baltazara Dobieszewskiego, posiadającego jednego zagrodnika, natomiast w 1588 roku tenże Baltazar był poświadczony jako właściciel jednego łanu kmiecego w tej wsi ${ }^{112}$. Własność w tych wsiach wyraźnie miała charakter drobnoszlachecki z elementami własności zagrodowej.

Odrębnym, ale interesującym i wartym przybliżenia przypadkiem, jest wieś Kamieniec w parafii Kłecko. W 1271 roku książę Bolesław Pobożny sprzedał Kamieniec swym ministeriałom, Jakubowi, Wojciechowi i Andrzejowi Miłoszowym, „z takimi prawami, jakimi cieszą się wszyscy szlachetni w Polsce”, i nadał im też immunitet sądowy. Mieli oni podle-

\footnotetext{
107 KDW, t. 7, nr 571, 634.

108 J. Karczewska, Wtasność szlachecka..., s. 68-69.

109 APP, Poznań Gr. 3, k. 143, 144.

110 A. Pawiński, op. cit., s. 159.

111 AGAD, ASK I 3, k. 551v.

112 AGAD, ASK I 3, k. 552; A. Pawiński, op. cit., s. 159.
} 
gać sądownictwu wojewody kaliskiego. Przynależność właścicieli Kamieńca do stanu szlacheckiego budzi wątpliwości; gdyby byli szlachtą, nie podlegaliby sądownictwu wojewody, w źródłach nie są określani jako nobilis. Z Kamieńca wywodzili się woźni sądowi gnieźnieńscy. Liber beneficiorum określa Kamieniec jako wieś, ... in qua nullus est cmetho, nisi ministeriales terrestres $^{113}$. Jednak jeszcze w 1441 roku w Kamieńcu byli jacyś kmiecie, ponieważ wydawca Liber beneficiorum przytacza informację o konflikcie o dziesięcinę, toczącym się w tym roku przed konsystorzem gnieźnieńskim między plebanem a miejscowymi kmieciami ${ }^{114}$.

Zapiski sądowe określają położenie i granice działów, części i łanów na ogół wtedy, gdy dochodziło do sporów granicznych i dokonywano ujazdów dóbr. Jednym z nielicznych takich przykładów jest wzmianka z 1469 roku, kiedy Jan Bylina z Grzybowa Wódek zrezygnował z płosy roli położonej od granic Malczewa do granic Mikołajewic ${ }^{115}$. Jeśli były to grunty przynależne do Grzybowa, to oznaczało, że była to wieś rozległa.

Częściej natomiast zapiski sądowe wymieniają nazwę działu (na ogół to był łan, czyli włóka), będącego przedmiotem transakcji - np. łany Łazanka i Łykowski w Grzybowie, część Drogoszewska, również w Grzybowie, część zwana Januszewska w Grzybowie Wódki, czy włóka nazwana Adamowska w Gulczewie ${ }^{116}$.

Działy we wsiach zagrodowych i drobnoszlacheckich znajdowały się w rękach dziedziców z różnych sąsiednich wsi. Szlachta cząstkowa z jednej wsi zagrodowej czy drobnoszlacheckiej posiadała drobne działy w sąsiednich wsiach o podobnym statusie - np. w 1494 roku Jan i Paweł Gostomscy posiadali dział w Małachowie Kępicz (Kępe) ${ }^{117}$, w 1497 roku Paweł

113 Liber beneficiorum..., s. 91.

114 Ibidem, przyp. 1.

115 APP, Gniezno Gr. 3, k. 38, 38v.

116 APP, Poznań Gr. 7, k. 142, 148; APP, Poznań Gr. 8, k. 134; APP, Gniezno Gr. 3, k. $54 \mathrm{v}$.

117 APP, Poznań Gr. 7, k. 49. 
Gulczewski, alias Wythacowski, miał część w Cielmowie ${ }^{118}$. Działy w tych wsiach kupowała także zamożniejsza szlachta folwarczna, np. w 1470 roku 7 dziedziców z Grzybowa Ołownego sprzedało część w tymże Grzybowie za 80 grzywien dziedzicowi z Wrześni ${ }^{119}$.

W okolicy Gniezna w badanym okresie napotykamy wiele nazw osad zanikłych lub zaginionych. Niektóre z nich mogły zostać wchłonięte przez sąsiednią wieś (np. Michałkowice przez Żółcz). Jest to niekiedy ślad podziałów tych wsi - często nazwa osady, którą przekazują źródła (na ogół odimienna, patronimiczna) to nazwa działu wsi z czasem wchłoniętego przez wieś macierzystą.

Podsumowując powyższe rozważania, można znów odwołać się do słów W. Dworzaczka:

...należy stwierdzić, iż w Wielkopolsce zachodniej, zwłaszcza w powiecie gnieźnieńskim, już w początkach XV w. istniały skupiska drobnych właścicieli ziemskich o cechach wyraźnie zaściankowych ${ }^{120}$.

Prześledzenie danych z ksiąg sądowych, Liber beneficiorum i rejestrów poborowych pozwala stwierdzić, że największy stopień rozdrobnienia wsie zagrodowe osiągnęły w XV wieku. Wynika to choćby z liczby przysiółków i działów w tych wsiach, np. Grzybowo, będące największą „okolicą” szlachecką w XV wieku liczyło 13 przysiółków, na początku XVI wieku było ich 7, a w 1564 roku - 5, oczywiście w każdym z nich było od kilku do kilkunastu działów liczących od ćwierci do dwóch łanów ziemi. Odpowiednio, w Małachowie dla XV wieku zidentyfikowano 6 przysiółków, na początku XVI wieku było ich 4 (i jeden opuszczony) a w 1564 roku już tylko 3 przysiółki. W połowie XVI wieku maleje liczba przysiółków i liczba działów majątkowych w nich się znajdujących. Natomiast w drugiej połowie XVI wieku części we wsiach zagrodowych kupowała możniejsza szlachta, np. w Małachowie - Przyjemscy i Wojciech Strzałkowski, który był też właścicielem działów w Grzybowie, w Cielmowie części posiadała wybijająca się rodzina Gurowskich. W ten sposób malała liczba właścicieli-miejsco-

118 Ibidem, k. 268.

119 APP, Poznań Gr. 8, k. 98.

${ }^{120}$ W. Dworzaczek, op. cit., s. 32. 
wych dziedziców, następowało zaś stopniowe scalanie własności ziemskiej w rękach zamożnej szlachty. Dawni zagrodowcy, wyzbywszy się rodzinnych działów, wybierali bądź to służbę u panów, bądź osiedlali się w okolicznych miasteczkach, niektórzy natomiast deklasowali się.

Przyczyn rozdrobnienia tych wsi można upatrywać w rozrodzeniu miejscowych dziedziców. Zapisy niektórych spraw dają pogląd o liczebności dziedziców w jednej wsi. Przywoływany wyżej dokument dotyczący prawa prezenty kościoła św. Wawrzyńca w Gnieźnie wymienia łącznie 28 dziedziców z Drachowa, Gurowa i z Cielmowa ${ }^{121}$. Gremialnie też dawano sobie świadectwo ${ }^{122}$, a także gremialnie najeżdżano na siebie $\mathrm{w}$ gronie sobie podobnych ${ }^{123}$.

Do interesujących wniosków doszedł Jacek Wiesiołowski, który zbadał strukturę społeczną mieszkańców powiatu gnieźnieńskiego, opierając się na ich deklaracjach majątkowych złożonych w XV wieku w sądzie konsystorskim w Gnieźnie. Wynika z nich, że gnieźnieńska szlachta zagrodowa dysponowała majątkami w wysokości do 30 grzywien, natomiast majątek rzędu 40-80 grzywien był charakterystyczny dla właścicieli ćwiartek lub mniejszych części wsi ${ }^{124}$. Według Joanny Karczewskiej, która zwróciła uwagę także na wysokość posagów i transakcji majątkowych szlachty gnieźnieńskiej, w grupie szlachty zagrodowej w połowie XV wieku posag wynosił 20-30 grzywien ${ }^{125}$. W tym czasie wydawanej za mąż mieszczance poznańskiej przeznaczano posag w wysokości 10-20 grzywien ${ }^{126}$. Poziom zamożności drobnej szlachty gnieźnieńskiej nie był więc wcale taki niski. Wydaje się, że wnioski J. Wiesiołowskiego co do kondycji majątkowej tej szlachty,

121 KDW, t. 10, nr 1622.

122 Przykładowo: Wielkopolskie roty sądowe, t. 2, Roty pyzdrskie, wyd. H. Kowalewicz, W. Kuraszkiewicz, Poznań-Wrocław 1960, nr 305, 575, 594, 642; Roty, t. 5, nr 336a.

123 APP, Gniezno Gr. 4, k. 13 (Maciej Gulczewski dokonał zajazdu „...cum viginti nobilibus....); APP, Gniezno Gr. 4, k. 23v (Piotr z Drachowa najechał z 6,...tibi familibus et octo inferioribus”); APP, Gniezno Gr. 4, k. 46v (Małachowscy z 6 „...sibi similibus nobilibus").

${ }^{124} \mathrm{~J}$. Wiesiołowski, Biedni, bogaci, przeciętni. Stratyfikacja społeczeństwa polskiego w końcu XVw., [w:] Biedni i bogaci, red. M. Aymard, Warszawa 1992, s. 150.

125 J. Karczewska, Wtasność szlachecka..., s. 320.

126 J. Wiesiołowski, Socjotopografia późnośredniowiecznego Poznania, Poznań 1997, s. $18-19$. 
można nawet nieco skorygować, bo niewykluczone, że szlachta mogła nieco zaniżać swój poziom majątkowy wymieniony w Depositiones testium z konsystorza gnieźnieńskiego. Według badań J. Wiesiołowskiego sytuacja własnościowa powiatu gnieźnieńskiego w XV wieku jest odbiciem relacji majątkowych panujących wówczas w sporej części Królestwa Polskiego, w którym przeważały ośrodki prowincjonalne podobne do gnieźnieńskiego ${ }^{127}$.

W powiecie gnieźnieńskim według rejestru poborowego z 1564 roku było wykazanych 3016 łanów, w tej liczbie 159 łanów stanowiło własność szlachty zagrodowej, niemającej kmieci ${ }^{128}$. Z tych liczb wynika, że w tym czasie łany szlachty zagrodowej w powiecie gnieźnieńskim stanowiły 5,3\% wszystkich łanów wskazanych w rejestrze. Nie jest to najpewniej liczba zupełna, daje jednak pewien pogląd na wielkość własności zagrodowej w Gnieźnieńskiem.

\section{The location of farmsteads and petty gentry villages in the poviat of Gniezno at the turn of the $15^{\text {th }}$ century}

(SUMMARY)

The farmsteads and petty gentry villages of the poviat of Gniezno situated in Kalisz voivodeship are concentrated in three main areas. The first and, at the same time, the largest such concentration was found in the territory located south of Gniezno - on a strip between Gniezno, Witkowo and Czerniejewo. The second was situated in the west of the poviat (Popowo, Łubowo parishes), whereas the last, small, complex comprised several villages in the parish of Trlag.

The chronological scope of the study covered the years from the turn of the $15^{\text {th }}$ century, while the source base was constituted by court records regarding the lands of Greater Poland (Wielkopolska), as well as the "Liber beneficiorum of the archidiosece of Gniezno" by Jan Łaski and - for comparative purposes - the $16^{\text {th }}$-century tax registers.

The villages were divided into parts, each provided with a binomial name the first component being the proper name of the village, whereas the second was

${ }^{127}$ Idem, Biedni, bogaci..., s. 145.

${ }^{128}$ http://hgis.kul.lublin.pl/mapy 
derived from a nickname or a name of its owner - heir. The farmstead villages inhabited by yeomen included: Grzybowo (initially an independent parish, later belonging to the parish in Gozdowo) consisting in the $15^{\text {th }}$ century of 13 divisions, Małachowo - sources inform of 6 existing divisions of this village; Jelitowo - with 2 divisions; Żółcz with 2 divisions; Cielmowo 5 divisions; Mikołajewice - 3 divisions; Drachowo - 5 divisions; and Bojenice, Skiereszewo and Gurowo. Nearby the above enlisted farmstead villages one could also encounter petty gentry villages managed by single peasants (e.g. Gulczewo). Local heirs often were owners of divisions in the neighbouring villages. The petty gentry and farmstead villages in the poviat of Gniezno were inhabited by noblemen of various coats of arms, with the only exception of Strzyżewo, where the landowners were the noblemen of the Poraj coat of arms.

In the vicinity of Gniezno it is possible to come across numerous names of no longer existing settlements. It is a direct result of partition of those villages - quite commonly the source name of a village was constituted by the name of a division absorbed in time by its mother village. The $15^{\text {th }}$ and $16^{\text {th }}$ centuries constituted the period of the most intense division of petty gentry and farmstead villages in the poviat of Gniezno.

Joanna Karczewska Instytut Historii, Uniwersytet Zielonogórski J.Karczewska@ih.uz.zgora.pl 


\section{SPROSTOWANIE}

"W 29 tomie „Klio. Czasopisma poświęconego dziejom Polski i powszechnym” (drugi numer opublikowany w 2014 roku) ukazał się artykuł autorstwa Joanny Karczewskiej „Rozmieszczenie wsi zagrodowych i drobnoszlacheckich w powiecie gnieźnieńskim na przełomie XV i XVI wieku” (numer DOI: $10.12775 / \mathrm{KLIO} .2014 .020)$. Niestety, z naszej winy nie podaliśmy informacji o tym, że autorem map dołączonych do artykułu jest Pan Michał Gochna z Zakładu Atlasu Historycznego Instytutu Historii Polskiej Akademii Nauk w Warszawie, za co przepraszamy zarówno autorkę artykułu, jak i autora map". 